Forrai Judit

\title{
Steinberger Sarolta, az első, Budapesten avatott doktornő
}

A nők egyetemre jutásának és azon belül az orvosi egyetemre való felvételének hivatalos kezdete Magyarországon a 19. század legvégén, 1895. december 19-én kiadott 65719. sz. törvényrendelethez köthető. ${ }^{1}$ Ez a rendelet, mely lehetőséget adott a nőknek egy köztiszteletben álló szakma megtanulására és végzésére, nagyon hosszú folyamat eredménye volt. A nőkutatás e területével az utóbbi félszázadban kezdtek el többet foglalkozni mind nemzetközi (Hawkesworth, ${ }^{2}$ Clement, ${ }^{3}$ Jefferson et al, ${ }^{4}$ Lorber, ${ }^{5}$ Riska ${ }^{6}$ stb.), mind hazai kutatók (Szögi, ${ }^{7}$ Gyáni, ${ }^{8}$ Jobst, ${ }^{9}$ Karády, ${ }^{10}$ Kéri, ${ }^{11}$ Forrai, ${ }^{12}$ Péter H., ${ }^{13}$ Kapronczay $^{14}$ stb). Jelen írás az első magyar orvosnők történetének egy fontos mérföldkövét, az első, Magyarországon egyetemre jelentkezett és itt is végzett magyar doktornőt, Steinberger Saroltát (1871. szeptember 12., Tiszaújlak - 1966. november 24., Budapest) mutatja be.

\section{A család}

Steinberger Sarolta apja Ugocsa megyei, tiszaújlaki földbirtokos volt. Steinberger Lipót a szabadságharcban részt vett honvéd, egyike volt a vidék legtekintélyesebb és legjótékonyabb földbirtokosainak, akihez bizalommal fordultak nem csupán a község, de az egész környék szegényei is. Később, 1891-től a helyi takarékpénztár részvénytársaságának felügyelőbizottsági tagja volt. ${ }^{15}$ Több lexikonban valóban szabadságharcosként említik az apát, azonban nem tudjuk, hogy e megállapítás csak később ragadt-e a családi krónikához, vagy a névazonosság miatt Lukácsy Sándor századfordulón bemutatott népszínművéből kiragadott-e ez a kép. ${ }^{16}$

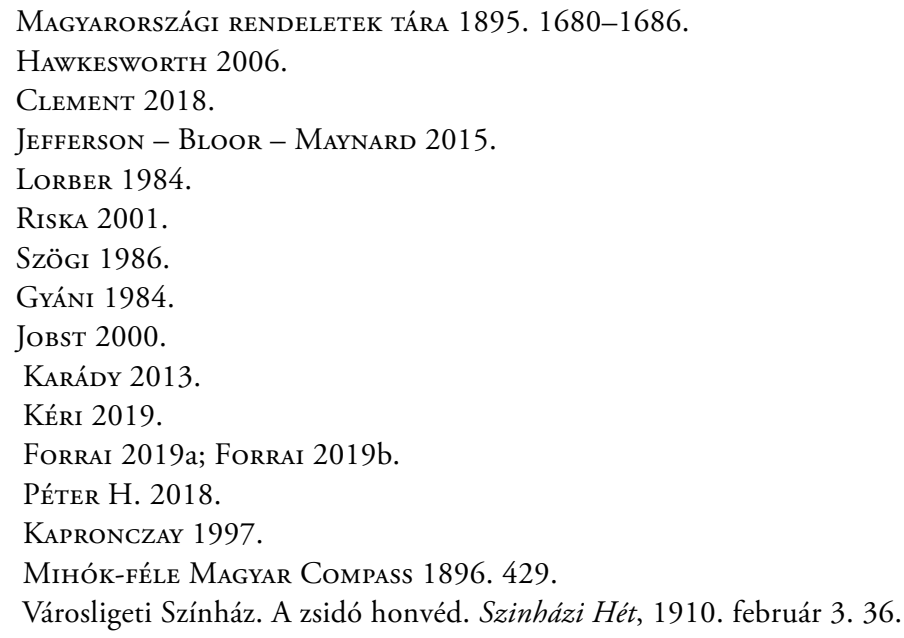


Steinberger Sarolta e jómódú zsidó család nyolc gyermeke közül hetedikként 1875 . szeptember 12-én született. Gimnáziumi tanulmányait - miután még a lányok nem járhattak gimnáziumba - magánúton végezte, az év végi vizsgáit a debreceni, majd a máramarosszigeti gimnáziumban kitűnő eredménnyel teljesítette. Érettségi vizsgáját Kolozsváron tette le, azt is kitűnő eredménynyel. ${ }^{17}$ Pályájára visszaemlékezve, 1962-ben hosszú interjút adott a Népszabadságnak, ekkor megfogalmazott önvallomása szerint egy helyi babona ébresztette rá, hogy valójában

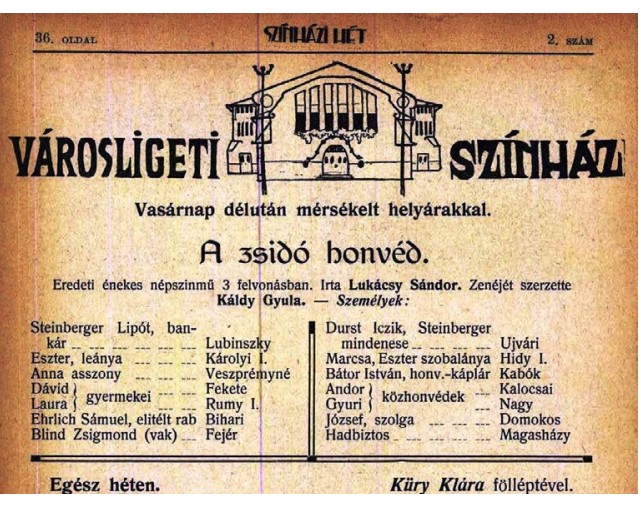

1. kép - A zsidó honvéd. Népszínmü gyógyító akar lenni:

„Tiszaújlakon, egy elmaradott kis faluban laktunk. Nyolcan voltunk testvérek, én voltam a hetedik. Ott, a faluban az a babona járta, hogy a hetedik gyereknek mindig gyógyitó a keze. Gyerekkoromban nem volt olyan betegség a faluban, ahová el ne cipeltek volna. Meg kellett tapintanom a beteget, hogy meggyógyuljon. Hol meggyógyult, hol nem, de hittek a kezem gyógyitó erejében. Ha véletlenül a pap rá nem beszéli a szüleimet, hogy tanittassanak, talán éppenséggel javasasszony lettem volna - mondja nevetve." 18

\section{Tanulás}

A Kolozsvári Református Kollégiumban tett érettségi vizsgája eseményszámba ment, melyről így írtak a sajtóban: „Osztályvizsgálatot már tett és pedig fényes eredménnyel, különösen a latin nyelvben és természettanban mutatott szép jártasságot. A kisasszony (...) az érettségi után Párisba megy orvosnövendéknek." 19 De nem így lett, nem Párizsba, hanem végül Zürichbe ment továbbtanulni. Követte a nagy előd, Hugonnai Vilma útját, ott két félévet járt az egyetemre. Mindenképpen szülész-nőorvos szeretett volna lenni.

Elkezdődött a szorgalmas és kitartó tanulás, a napi elismerésért való megküzdés, és ez bizony az első női orvosnövendékeknek életük végéig tartó, állandó napi harcot jelentett. Steinberger Sarolta életében is végig tudjuk ezt követni. Erről így emlékezett meg: „Több professzor sokszor az órákon megjegyzéseket tett, hogy hova jutott a világ: nö az orvosegyetemen! A férfi hallgatók sem mind fogadtak szivesen. Sokan úgy vették, mintha én, a leendö orvosasszony a kenyerükre pályáznék." ${ }^{20}$ Abban az időben még hallatlan konzervativizmus uralkodott a nők társadalmi szerepét illetően. Női egyenjogúságról alig-alig lehetett beszélni, az ezért küzdő mozgalmakkal szemben pedig a férfiak részéről gyakran megfogalmazódott a „jó ízlés” határát túllépő feminizmus vádja.

17 Steinberger Sarolta dr. Pécsi Napló, 1900. november 4. 6.

18 Szabó László: A doktor néni. Népszabadság, 1962. október 9. 6.

19 Tudós kisasszony. Budapesti Hirlap, 1892. május 21. 7.

20 Szabó László: A doktor néni. Népszabadság, 1962. október 9. 6-7. 

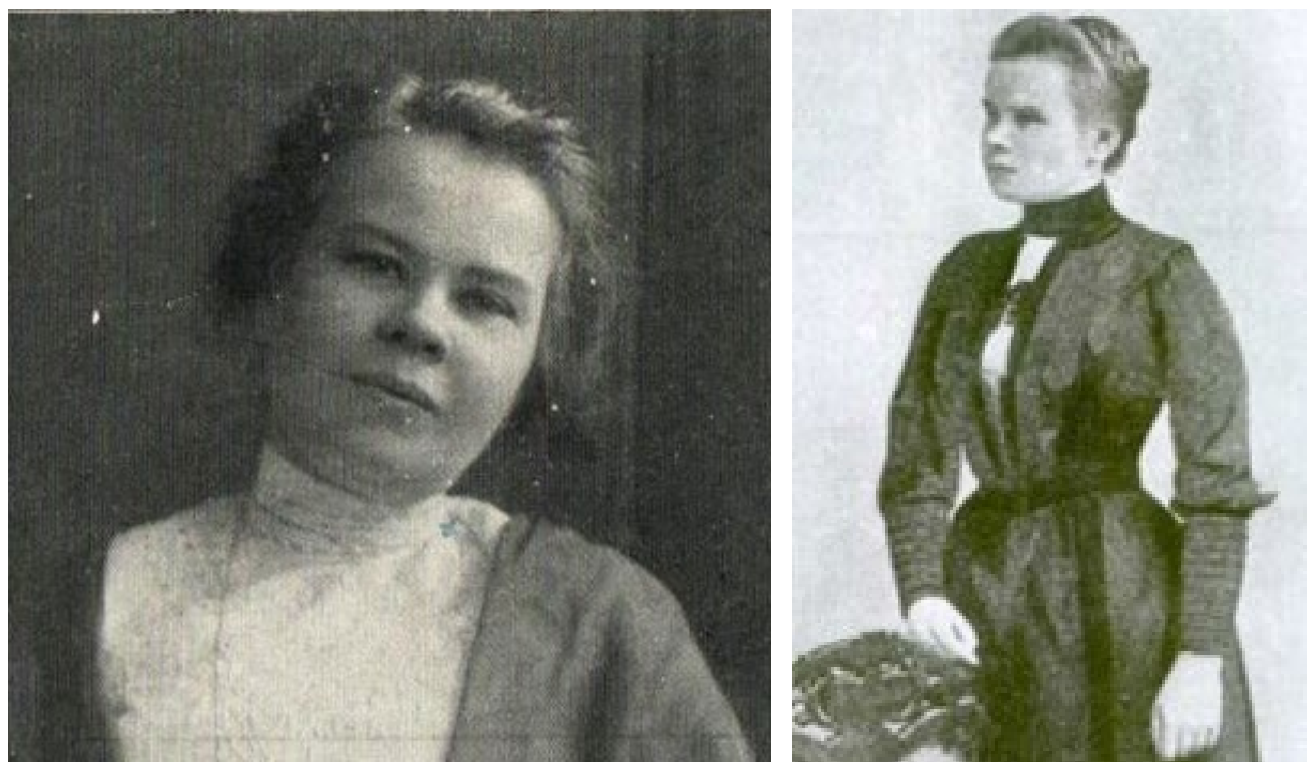

2-3. kép - dr. Steinberger Sarolta

Steinberger kisasszony egyetemi időszakában (1896-1900) a sok ismeretanyag befogadásával együtt élte a fiatal hölgyek életét, a tanulás mellett sportolt, táncmulatságra járt, amiről a közérdeklődésre számot tartó, társadalmi eseményekről szóló korabeli beszámolókban is olvashatunk: „A Fövárosi Sportkör 1897. a Magyar Vasúti és Hajózási Klub Andrássy-úti helyiségében hangversennyel egybekötött táncestet rendezett" ${ }^{21}$, melyen az asszonyok és leányok között Steinberger Sarolta is részt vett.

Az előadásokon és az orvosi gyakorlatokon Steinberger kisasszony az évfolyamában mint egyetlen női hallgató szerepelt. ${ }^{22}$ Az utána jövő évfolyamban ketten, Königsberger Lea és Szendeffy Ida már „kitaposott” úton jártak, a professzorok és a hallgatók is hozzászokhattak a nők jelenlétéhez az oktatás során.

Steinberger Saroltát 1900-ban avatták orvostudorrá, amelyről a napilapok szenzációként tudósítottak. A ceremónia az egyetem központi épületének aulájában előkelő közönség előtt, ünnepélyes keretek között zajlott. Az egyetlen avatandó doktorkisasszony hosszú fehér ruhában jelent meg, ezzel is kirítt a fekete frakkos urak sorából: „valóban, mint egy papnő jelent meg az ünneplö publikum elött." 23 A szokásos eskütétel és kézfogás után az orvoskari dékán, Bókay Árpád professzor „lendületes beszédet intézett hozzá, ecsetelvén a hivatás magasztosságát, a melynek a mai napon papnöjévé szegödött." 24

Egy másik „felbolydult”, az addigi rend megváltozását ecsetelő újsághír világosan megírta a női orvosok szokatlan helyzetét:

\footnotetext{
21 Fővárosi Sportkör 1897. Budapesti Hirlap, 1903. február 1. 11.

22 Nők az egyetemen. Gyógyszerészi Hetilap, 1896. november 1. 717.; Nők az egyetemen. Budapesti Hirlap, 1896. október 24.7.

23 Steinberger Sarolta dr. Pécsi Napló, 1900. november 4. 6.

24 Steinberger Sarolta dr. Pécsi Napló, 1900. november 4. 6.
} 
„Arról meg vitatkozni fognak a hozzáértök, helyes-e, nem-e, hogy erröl az eddig egészen kizárólag férfinak való pályára asszonyokat, pláne leányokat is bocsátanak, de mindenképpen nagy dolog az, hogy leányok belevágnak a nehéz tanulmányokba, s nemcsak úgy próbaképpen, hanem keresztül is viszik, amibe belefognak. Nagy könyveket bujnak, fáradsággal jegyzeteket csinálnak, vizsgálnak, tetemeket bontanak, mindezt annyi esztendön át úgyszólván reggeltöl estig. És végül annyira jutnak, hogy eleven embereket gyógyithatnak, merész kézzel, éles mütöszerszámokkal azokon operációkat is végezhetnek. (...) [D]r. Steinberger Sarolta kisasszony elérte már ezt a fokot, s hogy esztendöröl-esztendöre most már mind több fiatal hölgy megy ambicióval az orvosi pályára, a jövöre ö utána majd többen is következnek, $s$ majd azokkal is, mint ma Steinberger kisasszonynyal, kezet fognak a dékán és a többi tekintélyes tanárok és mondják majd nekik is: - Tudorrá fogadom!'25

Az egyik jól értesült kommentátor nem bírta megállni, hogy valami csipkelődést ne írjon e megható és különös ünnepi alkalommal: „Érdekes epizód, hogy a doktor kisasszony egyikben már mint menyasszony Hymen rózsa-lánczától körülövezve majdnem felesége lett egy szülövárosabeli orvosnak, de tudomány-szomja föláldoztatta vele a földi boldogságot, igy nagyobb dicsöséget és hirnevet szerezve úgy magamagának, mint kicsi kis szülövárosának." Az újságírói élcelödés az akkori közvélekedést tükrözte: vagy tudomány, vagy házasság, a kétféle karrier egy nőnél szinte kizárja egymást.

\section{Új fogalmak, elnevezések}

A nők doktorrá válásával elnevezésüket is meg kellett határozni. Az új jelenséghez új fogalom, kifejezés, új nyelvi alkotás kellett. A már végzett orvosnők sokat gondolkodtak saját elnevezésükön, hogy a megszólításukban benne legyen a doktori cím is úgy, hogy az addig megszokott és összenőtt „úr” (doktor úr) megszólítás nélkül alkossanak új megjelö-

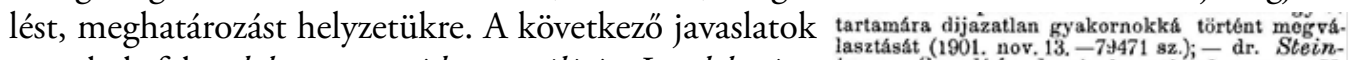

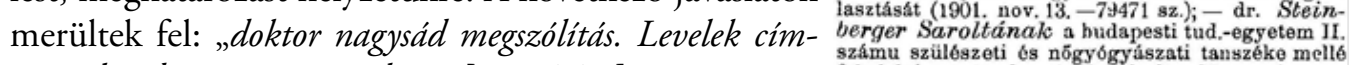

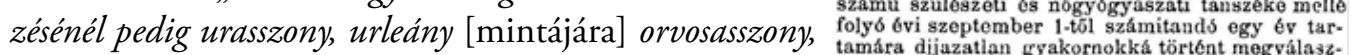
orvosleány. ${ }^{27}$ Később maradt a doktornő, doktoraszszony vagy egyszerủen a név után a doktori megjelölés.

4. kép - Gyakornoki megválasztás

Diplomája megszerzését követően Steinberger Sarolta, 1901-ben, egy évre díjtalan gyakornoki állást kapott a híres, újonnan felépült, korszerű, Tauffer-féle II. számú Szülészeti Klinikán. ${ }^{28}$ Komoly és kemény munka várt rá a tudományos igénnyel, magas szinten működő intézetben. Ennek megfelelően írta meg első cikkeit, melyek Tauffer segítségével az Orvosi Hetilapban folytatólagosan jelentek meg. A téma az orvosnők története volt a kezdetektől a századfordulóig, melyben a bábaság és a szülés körüli teendők egyetemes fejlődéstörténete is szerepelt. ${ }^{29}$ Az egyéves gyakornoki idő hamar eltelt, és Steinberger hamarosan máshol került alkalmazásba.

\footnotetext{
25 Dr. Steinberger Sarolta. Budapesti Napló, 1900. november 4. 6.

26 Steinberger Sarolta dr. Pécsi Napló, 1900. november 4. 6.

27 Orvosnők. Független Magyarország, 1903. december 25. 28.

28 Alkalmazások az egyetemen. Magyarország, 1901. október 30. 6.

29 Steinberger Sarolta: Az orvosnők története. Orvosi Hetilap Gynaekologia melléklete (1902):4. 90-93., (1902):5. 99-105., (1902):6. 120-127.
} 


\section{Munkába állás}

1902 májusában a tiszti főorvosnál „okleveleiket e hóban bemutatták: $d r$. Füredi Sándor, dr. Steinberger Sarolta, dr. Ladányi József, dr. Fischer Dezsö és dr. Hazai Sámuel egyetemes orvosdoktorok; és 5 szülésznón ${ }^{30}$, s ezzel az orvosi fizetés révén az adófizetők listájára kerültek. Ezt a folyamatot a tiszti föorvos a diploma bemutatása után indította el.

Steinberger Sarolta időközben fiatalabb kolléganőjével, Győri Ilonával az egészségtan tanári kurzust is elvégezte. Gyakornoki állását követően Máramaros egyik női fürdőjében fürdőorvosként ${ }^{31}$ is dolgozott. Akkoriban ritkaságszámba ment, hogy nő létére az elitebb szakmának számító balneológiát művelje. Visk ${ }^{32}$ fürdőhely igazgatósága meghívta az 1903-as évadra fürdőorvosnak:

„A derék és haladó szellemü fürdöigazgatóság modern gondolkodásának ad kifejezést életrevaló eszméjével és a szenvedö, finom érzékü prude nöi betegek bizonyára kedves és régvárt hírül veszik a nöemancipáció haladásának emez elsö fecskéjét annál is inkább, mert dr. Steinberger kisasszonyban nemcsak a komoly tudásnak és alapos készültségnek van meg minden kelléke, de azonfölül a végtelenül kedves, nagyon müvelt nönek minden egyszerü bája is érvényesül benne. A kisasszonynak, aki úgy Tauffer klinikáján, mint Párizsban és Németország nagyobb városaiban két évig gyakorolta magát, máris élénk praxisa van, bár az úttörök nehézségeivel még úgy ö, mint kivüle három orvosnö kollégája, névszerint: dr Königsberger Leon [!] orvostudor, dr Györi Ilona belgyógyász és dr Szende Ida gyermekgyógyász nagyon érzékenyen küzdenek." 33

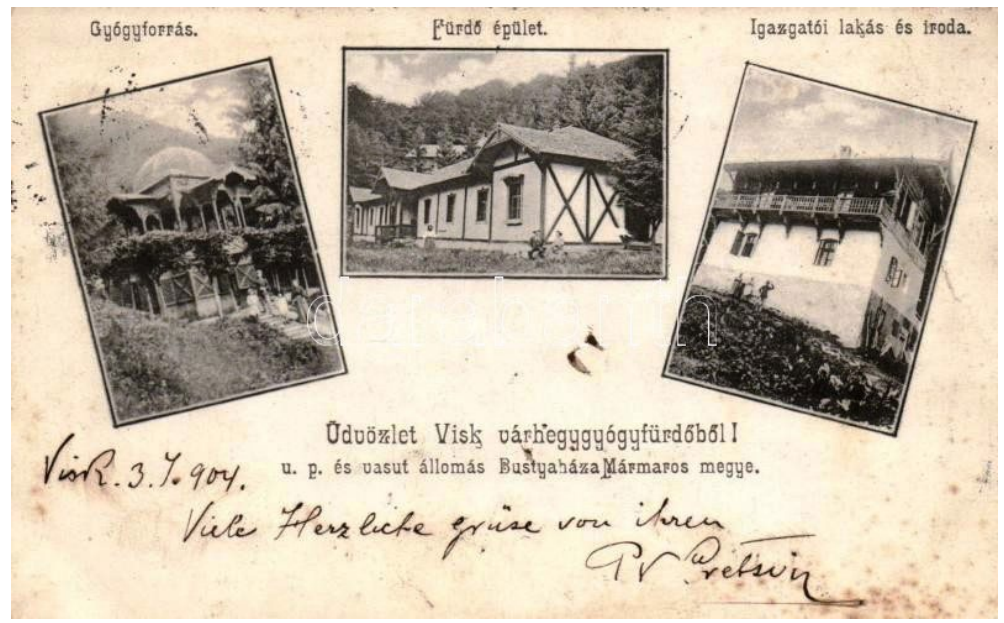

5. kép - Visk: várhegy gyógyfürdő, gyógyforrás, fürdő épület, igazgatói lak és iroda

30 Okleveleiket e hóban bemutatták. Fövárosi Közlöny, 1902. július 4. 965.

31 Orvosnők. Független Magyarország, 1903. december 25. 28.

32 Huszttól $20 \mathrm{~km}$-re délkeletre, a Tisza völgyében, a Marangos-patak partján fekszik. Visknek több ásványvízforrása van, az ásványvizet a viskiek borkútnak hívják. Az egykori (1818-1918) Magyarország-szerte híres várhegyi fürdő ásványvízforrása a szovjet érában történő higanybányászat következtében kiapadt. Szerepét a Saján-hegyi ásványvízforrások vették át. A gyógyhatású ásványvizek hasznosítása tette ismét országos hírűvé a Saján Szanatóriumot.

33 Az első nő-fürdőorvos. Pesti Hirlap, 1903. június 3. 10. 
A fürdőorvoslás, balneológia a legmodernebb szakterület volt, és megkívánta a legkvalifikáltabb orvosokat. Presztízse a szakmai hierarchiában a legmagasabb helyen állt a századfordulón.

\section{Női cölibátus és a tudomány}

Tauffer professzor 1911-ben a Nászutazás higiénéjéröl tartott elöadást. Érdekes módon a különböző orgánumok eltérő címekkel hívták fel a figyelmet a rendhagyónak számító elöadásra. Például $A$ nászút ${ }^{34}, A$ nászút egészségtana ${ }^{35}$, Intimitások a fórumon ${ }^{36}$, Nászútról és a vénlányokróß ${ }^{37}$, míg más cikkekben az előadások tartalmát emelték ki: Menstruatio higiénéjéröl, a Nászutazás higiénéjéröl, Férjhez nem ment nök testi és lelki egészségtanárób8, illetve Nászutazásról és a pártában maradt nök testi-lelki egészségtanáról (nöi cölibátusról). ${ }^{39}$ A professzor 1911-ben megtartott előadásának ${ }^{40}$ témája korjelző, $s$ szorosan kapcsolódik Steinberger doktornő és sorstársai, valamint más értelmiségi pályát választott nők elhivatott életére is. Azt a társadalmi jelenséget járta körül orvosi és közegészségügyi szempontból, hogy egyre több lett az önálló nő, akik el tudták tartani magukat, nem a férjhez menés volt az egyetlen céljuk az életben, hanem pályát, hivatást vállaltak a munkaerőpiacon. A kor gazdasági és erkölcsi irányai nem kerültek egymáshoz közel. Egy tisztes nő dolgozhat, lehet hivatása, többnyire nem megy férjhez, nem alapít családot, ugyanakkor érzelmi és szexuális igényei nem kerülnek kielégítésre. A férfiak megoldották a házasság mellett is e kérdést az évezredek óta működő prostitúció intézményével, amelyet a társadalom teljes mértékben befogadott a mindig meg-megújuló tiltakozás ellenére is. De mi lesz a női cölibátussal? Éri-e valamilyen szervi károsodás az egyedül maradt nőket?

Az Országos Közegészségügyi Egyesület hölgyosztálya az Anyák Iskolája címủ nagy érdeklődéssel kísért előadás-sorozatát Tauffer professzor az egyetem Gólyavárában tartott előadásával zárta. A pesti nők jöttek automobilon, kocsin, gyalog, villamoson tömegével. A „nászutazás higiénéje” és a "férjhez nem ment nök testi és lelki egészségtana” volt a tárgya az elöadásnak, amelynek „meghallgatására a pesti hölgyek siettek, tolongtak, taszigálódtak és boxolódtak. Öt órakor már tömve volt a nagy terem (...), föleg asszonyok, aztán leányok és feministák ültek, szorongtak, a padok tetejére álltak, hogy hallhassák Tauffer professzor szavát. Lárma volt, pisszeges, jajgatás, "mindjárt elájulok "kiáltozás." ${ }^{41}$

A hölgyosztály elnöke, Jakabné dr. Rácz Hanna nyitotta meg röviden az összejövetelt, utána Tauffer professzor megkezdte előadását. Arról a lehetetlen állapotról beszélt, amely még ma is, dacára a komoly helyekről jövő reformtörekvéseknek, a leánynevelés terén fennáll. Előadásának legérdekesebb pontja mégis kétségkívül a női cölibátus kérdése volt. Azt fejtegette, hogy a cölibátus a test egészségére nézve nem válik végzetessé, a legritkább

\footnotetext{
34 A nászút. Tauffer Vilmos előadása. Budapesti Hirlap, 1911. március 16. 7.

35 A nászút egészségtana. $A z U j s a ́ g, 1911$. március 17. 7.

36 Intimitások a fórumon. Pesti Hirlap, 1911. március 18. 8.

37 Nászutról és vén leányokról. Tauffer tanár előadása. Világ, 1911. március 16. 7.

38 Tauffer tanár előadása. Világ, 1911. március 14. 15.

39 Anyák iskolája. Magyarország, 1911. március 17. 11.

40 Nászutról és vén leányokról. Tauffer tanár előadása. Világ, 1911. március 16. 7.

41 Nászutról és vén leányokról. Tauffer tanár előadása. Világ, 1911. március 16. 7.
} 
esetben idéz elő szervi megbetegedéseket: „A nök nemi élete szoros kapcsolatban van érzelmi momentumokkal és nem tisztán az érzékek kielégitését szolgálja." "² Az absztinens életmódot folytató nőnél tehát az érzékek ki nem elégítése nem lesz a gyötrelmek kiapadhatatlan forrása.

Ami szenvedést okoz, az a gyermek utáni erős vágy és a társadalom oktalan megbélyegzése, a „vénlány” státusz. „Még ennél is súlyosabb megbélyegzés éri a leányanyát, azt, aki a természet parancsának engedelmeskedve, gyermeknek adott életet." ${ }^{33}$ Természettudományi alapon állva, csak barbarizmusnak nevezheti a társadalomnak ezt a cselekedetét: „unokáink bizonyára olyan csodálkozással tanulmányozzák majd egy civilizált világrend embertelenségét, mint mi szoktuk tenni ezt a középkor egynéhány hajmeresztö dolgával szemben." ${ }^{44}$ Hangsúlyozta, hogy a társadalmi felfogásnak meg kell változnia, és reményét fejezte ki, hogy az észszerübb nevelés ehhez nagymértékben hozzá fog járulni.

Nem a szerelem hiánya, hanem az anyaságra való vágyódás okozza a legnagyobb problémát Tauffer professzor szerint. Kijelentette továbbá, hogy a társadalomnak azon szokása, hogy kilöki a "kebeléröl” a leányanyákat, vagyis a „törvénytelen” anyákat, a „legnagyobb barbarizmus". A természet oltotta be a nőbe az anyaságra való vágyódást. A természet törvényeit pedig társadalmi szabályokkal nem lehet megdönteni. ${ }^{45}$

\section{Diszkrimináció}

A női orvosokkal szembeni előítéletekről a következőt mondta Steinberger doktornő a vasdiplomája átvétele (1960) után egy riportban: „Tény, hogy mind több nö követett az egyetemen, de az arány az utóbbi másfél évtizedig igen rossz volt. S persze, a társadalmi élet egyéb területeiröl nem is beszélek, hiszen a kilencszázas évek elején nemcsak a törvényhozással, hanem még a társadalmi elöitéletekkel is meg kellett küzdeni, hogy a nök és a férfiak elbirálása, alkalmaztatása egyenlö legyen." 46

1. eset: Az első ilyen komolyabb előítélet a Budapesti Királyi Orvosegyesület Gynekológus Szakosztályának 1901. december 10-én tartott XXXIV. ülésén érte. Kézmárszky Tivadar üdvözlő szavaival megnyitotta a tudományos értekezést, amelyen Steinberger Sarolta doktor kisasszony, valamint Czukor Miklós és Záborszky István doktor urak vendégként voltak jelen. Az eszmecsere a női betegségek balneoterápiájáról és a női bajok helyi gyógyításáról, valamint a fürdőhelyeken kialakult ellentétes nézetekről szólt, melyeket egyrészt a nőorvosok, másrészt a fürdőorvosok e kérdésben vallottak. ${ }^{47}$ Szakmai féltékenység és erkölcsi kérdések merültek fel a két szakma hatáskörét illetőleg. $\mathrm{Ki}$, mikor, hogyan és hányszor vizsgálja, vizsgálhatja meg a beteget a fürdőhelyen? Mi történik, ha vizsgálat nélkül rendelnek fürdőt, vagyis anélkül, hogy ismert lenne a páciens betegsége?

42 Nászutról és vén leányokról. Tauffer tanár előadása. Világ, 1911. március 16. 7.

43 Nászutról és vén leányokról. Tauffer tanár előadása. Világ, 1911. március 16. 7.

44 Nászutról és vén leányokról. Tauffer tanár előadása. Világ, 1911. március 16. 7.

45 A nászút. Tauffer Vilmos előadása. Budapesti Hirlap, 1911. március 16. 7.

46 Szabó László: A doktor néni. Népszabadság, 1962. október 9. 6.

47 XXXIV. ülés 1901. deczember 10-dikén. Orvosi Hetilap Gynaekologia melléklete (1902):1. 19. 
XXXIV. ülés 1901, deczember 10-dikén.

Elnök : Kézmárszky Tivadar; jegyzö : Tóth István.

Tóth Istcain: Az ỉlés megnyitása elött nem mulaszthatja el, hogy fel ne köszöntse a szakosztály tištelt és szeretett elnökét azon kitiintetés alkalmából, melyben részesült, bảr tudjuk mindnyájan, hogy menynyire ellene van minden ümnepeltetésnek. Csak a szeretetet és tiszteletet akarja kifejezésre juttatni, melylyel a szakosztály tagjai elnöküket körülveszik. Mindenkor a legnagyobb tisztelettel és szeretettel fogjuk továbbra is követni azon az uton, melyen minket vezet. Az Isten éltesse !

Elnök köszöni a szives megemlékezést. Megnyitja az iilèst ès jelenti, hogy három vendég van jelen: Steinberger Sarolta dr. k. a., Czukor dr. és Záborszky dr. urak. A jegyzökönyv hitelesitésére Lovrich ès Kubinyi tagokat kéri fel.

6. kép - Gynekológus estek

A jegyzőkönyvből kiderül, a Budapesti Királyi Orvosegyesület Gynekológus Szakosztályának nem tagja Steinberger dr., pedig mind gynekológiai, mind balneológiai ismeretei megfelelőek voltak. Meghívott vendég, tehát szakmailag elismerték, de kérése ellenére sem engedték belépni az elit szakosztályba. ${ }^{48}$

2. eset: A Budapesti Orvosi Casinot 1897-ben kiváló orvosok alapították mint szakmai érdekeltségü szervezetet; Széchenyi eredeti elvei alapján egyfajta szakmai elit találkozóhelyeként. Itt kedden délutánonként és vasárnap kellemes körülmények között tematizált szakkérdésekkel foglalkoztak, felolvasóesteket tartottak. A szakmai kaszinó teljesen civil felépítésben működött. 1904-ben Steinberger Sarolta kérte felvételét, amelyet elutasítottak. Az eset a feministák segítségével óriási sajtóvisszhangot kapott. Keményhangú cikkek jelentek meg, ${ }^{49}$ kritizálva a „férfi-clubot” védőket, akik genderkérdéssé változtatták a szakmai kérdést, vagyis a szakmát „androginizálták”. Egy ifjú női orvos kolléga, dr. Rácz Hanna ${ }^{50}$ mint az egyetlen női hozzászóló egy latin közmondással kezdte: Lucus a non lucendo (azaz világos, mint a vakablak). Az alapszabályra hivatkozva sorra döntötte meg az elutasítás törvényességét, ugyanis a felvétel kritériuma az volt, hogy az orvos feddhetetlen jellemü legyen, ez lucus, vagyis világos. Egyszerre két orvos jelentkezett felvételre: elvégezték az egyetemet, szigorlatoztak, diplomájuk van, csak az egyik férfi, a másik nő. A férfit felvették, a nőt nem, ez non lucendo. Szavazást rendeltek el a felvételről, az eredmény 14 ellene, 18 mellette. Mivel 2/3-os igen szavazat kellett a felvételhez, így „medicinae universae doctor Steinberger Saroltát a Budapesti Orvosi Casino választmánya nem vette fel tagjai közé." 51

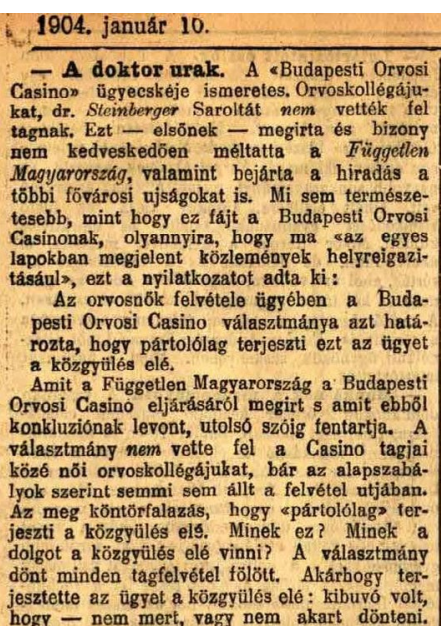

7. kép - A Budapesti Orvosi

Casinoba való belépés elutasítása

\footnotetext{
48 XXXIV. ülés 1901. deczember 10-dikén. Orvosi Hetilap Gynaekologia melléklete (1902):1. 19.

49 A doktor urak. Független Magyarország 1904. január 10. 9.; Dr. Steinberger Sarolta ügyében. Független Magyarország, 1904. január 8. 8.

50 Dr. Rácz Hanna (dr. Jakab Lászlóné) gyermekorvos, több orvosi könyve jelent meg.

51 Lucus a non lucendo. Dr. Steinberger Sarolta esete. Független Magyarország, 1904. január 6. 9.
} 
A lap prominens professzorok véleményét is kikérte az ügyről, akik a következő válaszokat adták: Müller Kálmán főrendiházi tag, az Országos Közegészségügyi Tanács elnöke, miniszteri tanácsos, a Dunabalparti Kórházak igazgató főorvosa elmondta, hogy a vezetése alatt álló kórházakban már két nőorvost alkalmazott. Müller úgy vélte, hogy amelyik nőnek diplomája van, természetes, hogy minden irányban ugyanazok a jogai vannak, mint a férfi orvosdoktornak - Steinberger felvételét tehát támogatta. Korányi Frigyes egyetemi orvosprofesszor, förendiházi tag: „A női kérdés egy általános kérdés, amelyböl egyes részeket kiszakitani nem lehet, különösen pedig nem egyes esetekröl, amelyeknek a körülményeit nem ismerem" ${ }^{22}$ - nyilatkozta Korányi Frigyes egyetemi orvosprofesszor, förendiházi tag, amit a Független Magyarország újságírója mellébeszélésnek, „circumspectus”-nak minősített.

Bókay János (1858-1937) egyetemi orvosprofesszor, a Stefánia-gyermekkórház igazgató-fóorvosa nem nyilatkozott, de szerinte várni kell, miképp válnak be az orvosnők, tehát ellenezte felvételüket a Casinoba. Navratil Imre egyetemi sebész professzor szerint az alapszabályt revideálni kell, fel kell venni a nőket. Bársony János egyetemi professzornak közömbös volt, felveszi-e a Budapesti Orvosi Casino tagnak a nőket vagy sem; Feleki Hugo egyetemi magántanár a kaszinóbeli társalgásnak esetleges szabadabb hangja miatt aggódott, de azért az volt a nézete, hogy a nőket fel kell venni tagnak, ha már folyamodnak - bár szerinte az nem helyes, hogy folyamodtak. Nékám Lajos egyetemi tanár azt helyesnek tartotta, ${ }^{53}$ hogy felvették a nőket a tisztán tudományos célzatú orvosi egyesületekbe, de a kaszinóban előfordulható szabadabb beszéd gondolkodóba ejtette. A komoly, fondorlatos diplomáciai nyelvezet többnyire - bár finoman - az elutasítást takarja.

3. eset: Az évek múlásával a megalakult biztosítótársaságok alkalmazott orvosai között ott találjuk Steinberger doktornőt, aki az Országos Társadalombiztosító Intézet (OTI) nőgyógyász főorvosaként rendelt. Orvosi munkájáról, a korabeli sajtót vizsgálva, szinte szenzációként írták a lapok 1937-ben, hogy gondatlanságból okozott emberölés vétsége címén indult bủnvádi eljárás dr. Steinberger Sarolta, az OTI osztályvezető főorvosa ellen. ${ }^{54} \mathrm{Az}$ orvosnő az OTI nőgyógyászati osztályán megvizsgált egy beteg asszonyt, és miután csak kezdődő betegséget állapított meg, arra utasította, hogy egy-két hét múlva újból jelentkezzék. Az asszony nem fogadta meg a tanácsot, csak hetek múlva jelent meg ismét a rendelőben, de ekkor már olyan rosszul volt, hogy azonnali mütéttel sem tudtak rajta segíteni, így meghalt. A törvényszéki orvos, dr. Orsós Ferenc szakvéleménye szerint ${ }^{55}$ Steinberger Sarolta már az első vizsgálat alkalmával megállapíthatta volna, hogy milyen betegségről van szó. Tehát gondatlanul járt el, amikor a beteget későbbi jelentkezésre utasította. Ezért gondatlanságból okozott emberölés vétségében bűnösnek mondták ki a doktornőt, és ezer pengő pénzbüntetésre ítélték. ${ }^{56}$

52 Lucus a non lucendo. Dr. Steinberger Sarolta esete. Független Magyarország, 1904. január 6. 9.

53 Dr. Steinberger Sarolta ügyében. Független Magyarország, 1904. január 8. 8.

54 Gondatlan emberöléssel vádolt föorvosnő. Új Nemzedék, 1937. október 27. 9.

55 Orsós Ferenc dr. (1928-1945), aktív szélső jobboldali politikai szerepvállalásáról is ismert, fajvédő magyar patológus, egyetemi tanár, az MTA tagja.

56 Orsós professzor lesujtó véleménye az OTI-ról egy törvényszéki tárgyaláson. Magyarország, 1937. október 27. 14 . 


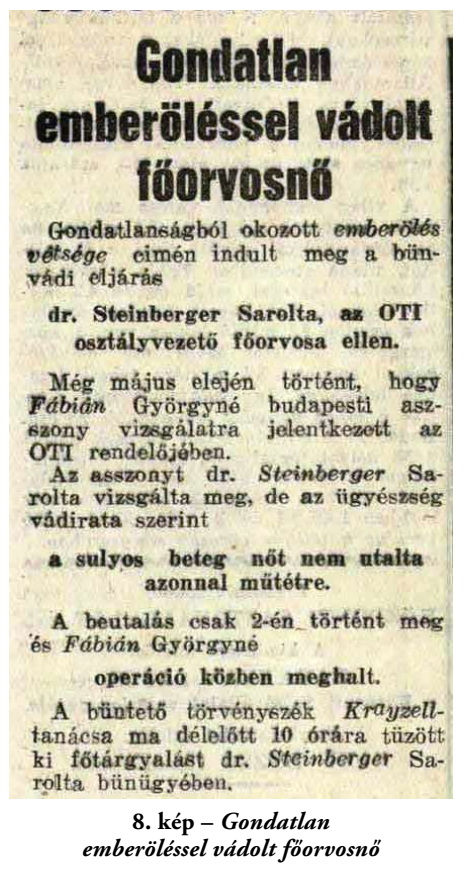

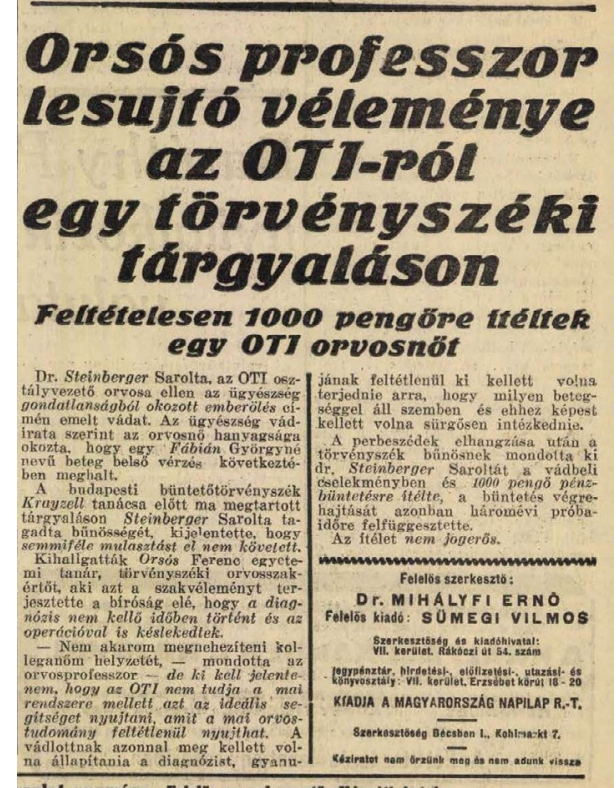

9. kép - Orsós professzor véleménye

Azt nem tudjuk, Orsós Ferenc professzor véleményét mennyire befolyásolta ez ügyben a zsidókról kialakított általános véleménye, és ez esetben Steinberger Sarolta zsidó orvosnő ügye, de azt igen, miként érvelt a teljes faji elkülönítésről a későbbi harmadik zsidótörvény (fajvédelem) tárgyalásán az Országgyűlés felsőházában, az Orvosi Kamara képviseletében. ${ }^{57}$ Az is közismert volt róla, hogy hivatali képviselőként 1944-ben, a német megszállás után Csik Lászlóval, az Orvosi Kamara akkori elnökével együtt a belügyminisztériumhoz benyújtott közös kérvényben sürgették ${ }^{58}$ a hatóságokat, hogy az addig megkímélt, polgári munkaszolgálatban alkalmazott zsidó orvoskollégáikat mielőbb deportálják. Ennek az akciónak a háború után végzett becslések szerint mintegy 2500 orvos esett áldozatul, az ország zsidó orvosainak több mint a fele. Nem véletlen, hogy a németek visszavonulásával együtt Orsós örökre elhagyta Magyarországot. Ám dr. Steinberger Sarolta föorvos ügyében másodfokon, magasabb szinten tovább folyt a vizsgálat. A Legfelsőbb Igazságügyi Orvosi Tanács szakvéleménye alapján a Tábla megállapította Steinberger Sarolta ártatlanságát és jogerősen felmentette. ${ }^{59}$

\footnotetext{
57 A házassági jogról szóló fajvédelmi rendelkezésekről kiadott, a nürnbergi törvényeken alapuló 1941:XV. törvénycikk már a zsidók és nem zsidók közötti társadalmi kapcsolatok felszámolását tekintette céljának. Az 1941. augusztus 8-án, Bárdossy László miniszterelnöksége alatt életbe lépett törvény megtiltotta a zsidók és a nem zsidók házasságkötését, illetve a házasságon kívüli nemi kapcsolatot börtönbüntetéssel szankcionálta. Teljessé vált a magyar zsidóság törvényileg szabályozott elkülönítése a hazai társadalomban a nemzsidók részétől: „Ami most a fajvédelmi javaslat 9. S-át illeti, itt több oldalról elhangzott az, hogy beleütközik a természeti törvénybe, ha megakadályozza a zsidók és keresztények házasságkötését. A természet törvényeiben a tudomány a faj legmesszebbmenö védelmét figyelte meg. A faji korlátok áttörése nem a természeti törvény, hanem az egyéni nemi ösztön természet elleni jelensége, tapasztalat szerint káros kivétel." - hangzott el Orsós Ferenc érvelése. Orsós 1942. 296. Lásd még: Pelle 2018; Orsós 1937.

58 Magyar 2018. 100-104.

59 Felmentettek egy OTI orvosnőt az emberölés vádja alól. Friss Újság, 1938. december 24. 5.
} 


\section{Szülész-nőgyógyászi munka}

Steinberger doktornő a Budapesti Kerületi MunkásBiztosító Pénztár rendelőintézetei ${ }^{60}$ közül először a Dob utcai, később a Csengery utcai nőgyógyászaton dolgozott. A biztosító egyéb egészségügyi szolgáltatásainak helyei a fővárosban több rendelőben mủködtek Budán, Pesten a Ferencvárosban, Kőbányán egyaránt. ${ }^{61}$ 1927-ben átszervezték az intézményt, az Országos Társadalombiztositó Intézet nevet kapta. Steinberger Sarolta doktor rövidesen az OTI főorvosa lett, munkásnőket kezelt igen nagy odafigyeléssel, kiváló szaktudással. 1962-ben készült riportjában a doktornő így számolt be az ott eltöltött hosszú évekről:

"Mint egykori munkásorvos, ho-
gyan emlékszik vissza ezekre az idökre? - Igazán kellemesen. Tudja, úgy van ez, hogy minden orvos szereti, ha a betege szófogadó, aláveti magát az utasitásainak, sföleg, ha nem nyafog. Voltak nekem gazdag betegeim, s azok között olyanok is, akiket megszerettem. De a munkásasszonyokat valahogy másként szerettem. Jól éreztem magam közöttük, ahogy mondani szokták, igazi jó betegek voltak. $S$ föleg hálásak. Nem anyagilag, hiszen soha nem törekedtem vagyonszerzésre." 62

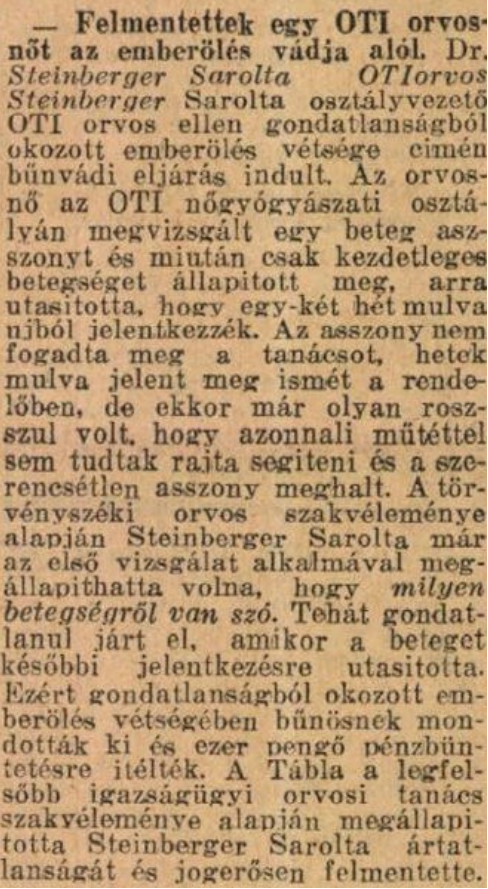

10. kép - Dr. Steinberger Sarolta felmentése

Az 1900-tól az 1910-es évekig a nemzetközi és hazai gyógyítás, a szanatóriumi élet fényes korszakát élte, különösen a balneológiát tekintve, amely a kor legmodernebb terápiás eljárása volt. A Munkásbiztosító vezetője, dr. Friedrich Vilmos királyi tanácsos, egyetemi tanár, valamint a nőgyógyászati osztály vezetője, dr. Temesváry Rezső (a Csengery utcai nőgyógyászat vezetője) másik két taggal együtt megalakították a Székesfővárosi Egyetemes Szanatórium és Vízgyógyintézeti Részvénytársaságot, és városi szanatóriumot hoztak létre mérsékelt áron azoknak, akik nem tudták megfizetni az akkor divatos hegyvidéki helyeken lévő szanatóriumi árakat. Nem csodálkozhatunk, ha az alapító részvényesek között megtaláljuk dr. Steinberger Saroltát is. ${ }^{63}$

\footnotetext{
60 Budapesti CZim- ÉS LAKÁSJEgYZÉK 1910. 306.

${ }^{61} \mathrm{Az}$ említett rendelőintézetek: Damjanich u. 5., Dob u. 74., Hársfa u. 13-15., Damjanich u. 36. , Ferenczvárosi rendelőintézet: gr. Haller u. 48., Budai rendelőintézet: Margit körút 25.; Kőbányai rendelő intézet: Martinovich tér 3. Főorvosok: dr. Friedrich Vilmos kir. tanácsos, egyetemi magántanár, dr. Csillag Zsigmond. Helyettes föorvosok: dr. Mándoki Mór, dr. Jurkinyi Emil, főorvosi titkár: dr. Hajnik Emil. Nögyógyászat (Dob u. 74.): dr. Temesvári Rezső, egyetemi magántanár, dr. Breitenfeld Ferencz, dr. Steinberger Sarolta, dr. Rotter Henrik. Budapesti Czim- ÉS LAKÁsjegyzéK 1910. 306.

62 Szabó László: A doktor néni. Népszabadság, 1962. október 9. 6-7.

${ }^{63}$ Felhívás a Székesfövárosi Egyetemes Szanatórium és Vízgyógyintézet Részvénytársaság részvényeinek jegyzésére. Pesti Hirlap, 1907. augusztus 18. 50.
} 


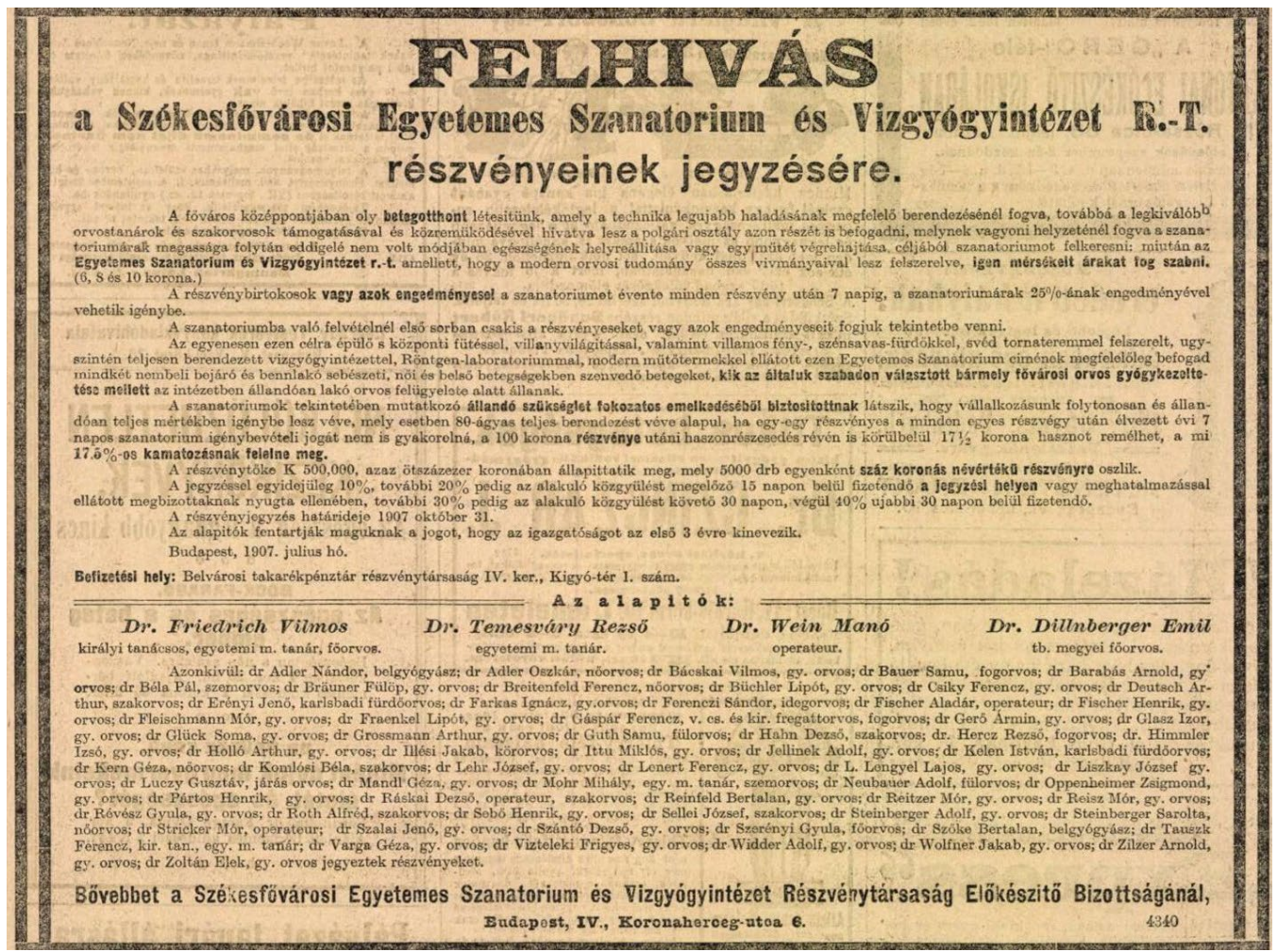

11. kép - Felhívás a víz- és gyógyvíz-részvény jegyzésére

\section{Társadalmi, civil tevékenység}

Steinberger doktornő elkötelezett híve volt a civil munkának, előadásokat tartott nőknek, fiatal lányoknak nemi felvilágosítás, higiéné, fertőző betegségek stb. témákban hosszú éveken keresztül. A Feministák Egyesületénél, ${ }^{64}$ a Nőtisztviselők Országos Egyesületében és mindenhol tartott előadást, ahová meghívták.

Alapító tagja volt az 1903-ban indult Magyar Nők Közmívelődési Körének. Már a megalakulás előtti szervezésben és az alapszabályok lefektetésében is aktívan részt vett. Ezeken a megbeszéléseken jelen voltak: gróf Teleky Sándorné, Emich Gusztávné, Zipernovszky Károlyné, Szende-Dárday Olga, özv. Komócsy Józsefné, Drescher Irma, Hertzka Elza, dr. Győry Ilona, dr. Steinberger Sarolta, Geöcze Sarolta, dr. Simay Gyuláné. ${ }^{65}$

A Magyar Nők Közmívelődési Köre alakuló közgyűlését 1903. december 14-én tartották az Otthon-kör dísztermében. Szép számú, előkelő hölgyközönség jelent meg az ülésen, melyen báró Dániel Ernőné elnökölt. A közgyűlést özv. Zempléni P. Gyuláné nyitotta meg, majd Tutsekné Bexheft Lilly érdekes, szép beszédben fejtette ki az egylet célját; a kör otthona lesz a szellemi munkával foglalkozó asszonyoknak; emellett a társadalmi

64 Egészségtani előadások nők számára. Magyarország, 1906. január 21. 11.

65 A Magyar Nők Közmivelődési Köre. Pesti Napló, 1903. november 28. 15. 
pozíciójuk megerősítését, érdekeik megóvását tűzte ki céljául: „Azok, akik kint küzdenek az életben, egyedül, önállóan, találják meg a körben azt az úri tónust, szórakozást, melyhez, mint szellemi munkával foglalkozó nöknek jussuk van. A társaság asszonyainak alkalmuk nyilik megismerkedni a szellemi munkával foglalkozó világ nöi képviselöivel." ${ }^{\prime}$ Székhelyük Budapesten, a Váczi utca 9. szám alatt volt.

Az egyesület tisztikara így alakult meg:

Elnök: báró Dániel Ernőné.

Tiszteletbeli elnökök: gróf Apponyi Albertné, Beöthy Zsoltné, Gyarmathy Zsigáné, Rákosi Jenőné, gróf Teleki Sándorné, Széll Kálmánné.

Alelnökök: Gömbösné Galamb Margit, Fröhlichné Móricz Paula, iff. Lónyay Sándorné, Tormay Cecil.

Dísztagok: Beniczkyné Bajza Lenke, Csiky Kálmánné, Emich Gusztávné, Gineverné Györy Ilona, Haracsek Lászlóné, Hernádi Mórné, Hertzka Elza, Jelinek Arthurné, Kasztner Janka, dr. Mandello Gyuláné, Rudnay Józsefné, dr. Schwarcz Gusztávné, gróf Vigyázó Sándorné, Zipernovszky Károlyné.

Ügyvezető: özv. Zempléni P. Gyuláné.

Titkár: Tutsekné Bexheft Lilly.

Jegyző: dr. Maksziányi Dezső.

Pénztárnok: dr. Farkas Gyuláné.

Orvosok: dr. Rácz Hanna és dr. Steinberger Sarolta.

Könyvtáros: Barkóczy Jolán.

A választmány tagja lett: Barkóczy Angyalka, b. Braun Decker Stina, Bruck Hermin, B. Büttner Helén, Császárné Alszegi Irma, Csillag Teréz, Czóbel Minka, D. Ligeti Juliska, Drescher Irma, özv. Fadrusz Jánosné, Felekyné Munkácsy Flóra, gr. Festetics Andorné, Feszty Árpádné, dr Fried Margit, Geöcze Sarolta, dr. Győry Ilona, Hampelné Pulszky Poliyxena, Hentaller Elma, Horváth Janka, dr. Katonáné Madarász Adeline, özv. Komócsy Józsefné, Kruzsélyi Erzsike, Lengyel Laura, Lux Terka, Márkus Emília, Molnár Lászlóné, özv. Nendtwich Gusztávné, Arth Ambrusné, Pártosné Bartolucci Viktória, özv. Paulay Edéné, Ráthonyiné Maróthy Margit, Ritoók Emma, Rosenberg Auguszta, Sárosi Bella, Schönherr Antalné, Sebestyénné Stetina Ilona, Somlóné Vadnay Vilma, Blaha Lujza, Strobel Zsófi, Szacsvayné Emma, Szabóné Szentpály Janka, Szabóné Nogall Janka, Szegedi Maszák Hugóné, Szende Dárday Olga, dr. Szendeffy Ida, Szilágyiné Drescher Jenny és Táboriné Tutsek Anna. ${ }^{67}$

6 A Magyar Nők Közművelődési Köre. Pesti Hirlap, 1903. december 14. 7.

67 A Magyar Nők Közmivelödési Köre. Független Magyarország, 1903. december 14. 8. 
Steinberger Sarolta folyamatosan tartotta az előadásait a női szervek anatómiai és funkcionális helyzetéről, az ún. női higiénéről, s minden olyan témáról, amelyről nem hallhattak sokat addig az orvosoktól hallgatói. A doktornő könnyebben találta meg a hangot a női hallgatóságával. Felvilágosító előadásait esténként a napi munka után tartotta olyan helyiségekben, ahova a dolgozó nők szívesen elmentek, szégyenkezés nélkül beszélhettek ún. „női” témákról: „A Feministák Egyesületének egészségtani tanfolyamán Steinberger Sarolta dr., gyakorló-orvos szombaton, január 20-án este hetedfél órakor folytatja elöadásait a Közgazdasági Társaság

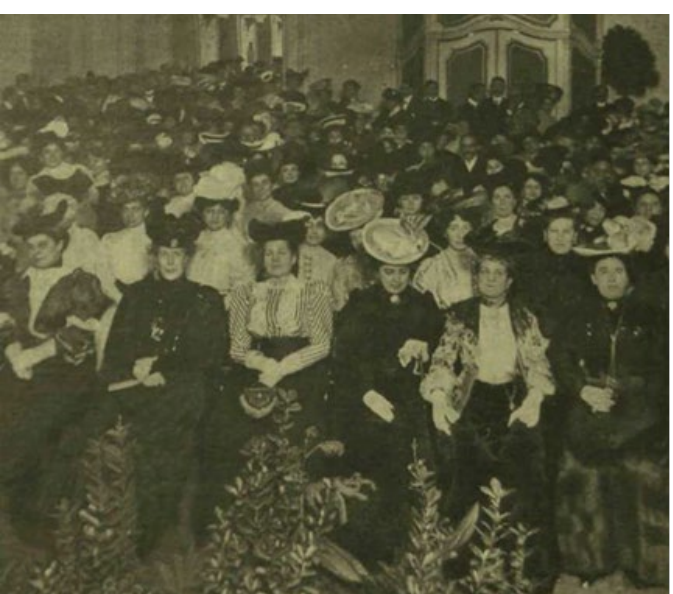

12. kép - A Magyar Nők Közmívelődési Körének zsúrjáról termében (IV., Ferenciek-tere 4.) Ezúttal az anyaság higiéniájával foglalkozik." ${ }^{8}$ - hirdette elődását 1906-ban a Budapesti Hirlap.

A Magyarország a doktornő egészségtani előadásaira hívta fel a figyelmet: „Steinberger Sarolta dr. gyakorló-orvos január hó 27-én szombaton este fél 7 órakor fejezi be a Feministák Egyesületében nök számára tartott tanfolyamát a Közgazdasági Társaság termében. (IV., Ferencziek tere 4. em. balra.)" ${ }^{69}$ A női élet funkciójáról pedig 1907-ben tartott előadást. ${ }^{70}$

A női funkciókkal foglalkozó előadások mellett társadalmi női szerepekkel, tanulással, munkerőpiaci megjelenéssel, jogi és politikai nézetekkel, szervezkedéssel is foglalkoztak ezek az előadások, így a felelős, társadalomba integrálódott nőtípusok széles skáláját tárták a hallgatóság elé. A Magyar Nők Közmívelődési Körének tagsága a megalakulástól kezdve igen aktív munkát végzett. Az 1910-es tudományos előadás-sorozatot a munkásegyesületek számára rendezték január 21-én, pénteken este 20 órakor. Az előadók és az előadások a következők voltak: Somogyi Béla: $A$ nö az iskolában; Kunfi Zsigmond: $A$ nö és a választójog; Weltner Jakab: A külföldi munkásnömozgalom; Ladányi Ármin: $A$ nö jogi helyzete; Pfeifer Sándor: $A$ nö és a szövetkezeti mozgalom; Steinberger Sarolta: $A$ nö egészségtana (ez utóbbi csakis nők számára szólt); Gárdos Mariska: A szocializmus; Stein Fülöp: Az idegbetegség megelözése. ${ }^{71}$

1912-ben a Nőtisztviselők Országos Egyesületében a XIV. rendes közgyűlés alkalmával a Kereskedelmi és Iparkamara helyiségében a munkahelyi higiénéről tartott előadást Steinberger Sarolta, a tagok élénk részvétele mellett. Képviseltette magát a közgyülésen a Magántisztviselők Országos Szövetsége is. Gergely Janka elnöki megnyitójában kiemelte azokat az érdekes jelenségeket, melyek a tisztviselők szervezkedése terén a közelmúltban észlelhetők voltak. Azután Wilhelm Szidónia, az egyesület titkára terjesztette elő a választmány jelentését. Steinberger Sarolta előadása pedig az irodahelyiségek higiénéjéről szólt. ${ }^{72}$

68 A Feministák Egyesületének egészségtani... Budapest Hirlap, 1906. január 20. 12.

69 Egészségtani előadások nők számára. Magyarország, 1906. január 21. 11.

70 Egészségügyi előadások munkásoknak. Népszava, 1907. január 17. 9.

71 A munkásnőegyesület tudományos előadás-sorozatot rendez... Népszava, 1910. január 21. 10.

72 Az irodahelyiségek higiénéje. Világ, 1912. április 26. 11. 


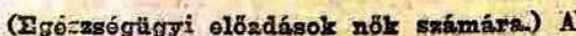
Feministát Egyesülatêbon ir. Stein berger Sarolta orvos e hórap 18-ikán kezdite meg elobadásait nagyszámu Dô:zözönség elött. Bevezetésképpen rêzzletesen ismertette az emberi szervezet strukturajiát. További eloadásaiban foglalkozik majd a nő higiéniájával, ismertetni fogja a nó szervezetének különleges fizikai kōvotelményeit. $\Lambda$ legközelebbi elỏadást dr. Steinberger szombaton este fél 7 brakor tartja a Közgazdasáai Társaság nagytermében (IV., Ferenciek-tere 4) A belépódij vendégeknek 40 fillér, egész tanfolyamért két korona.

13. kép - Egészségügyi előadások nők számára

\section{Mindent Tudok, az Ujság évkönyve}

Az Ujság-nak az érkönyve az idèn szokatlanul gazdag és páratlanul értékes tas talommal jelenik meg. Az idei évkönsy

a nö lexikona

less. A cikkekk egćsz légioja fejtegoti ezt a kérdest s a komoly tanulmányok a nỏ testi és szellemi életét

Az orvosi rész összeállitảsára az Ujság a legkitünöbb szakembereket nyerte me Mindent Tudok orrosi részét

Bodon Károly dr. egyetemi $m$. tanár, egészségügyi fôtanácsos, Mannsfeld Otté dr. egyeteml m. tanár, föorvos, Preisich Kornél dr. egyetemi m. tamann Sándor dr., fỏorvos és mások irták.

14. kép - Mindent Tudok-előadások

1913-ban Budapesten tartották meg a Nők Világkongresszusát, melynek szervezésében aktívan részt vettek a női egyesületek, feministák, és mint előkészítő-bizottság, meghatározták a kongresszus munkaprogramját. ${ }^{73}$

A nők iskolázásának kérdéséről előadás-sorozatot szervezett a Feministák Egyesülete 1925-ben, ahol többek között a közegészségügyi és szociális munkára való képzésről is beszéltek. Míg Ibrányi Alice az ápolónők képzésével foglalkozott, addig Steinberger Sarolta a bábaképzést tárgyalta. Lukács Sarolta a családgondozásról, Götll Mária pedig a pártfogó tisztviselőnők képzéséről tartott előadást. ${ }^{74}$

1928-ban $A z$ Ujság sorozatot indított felvilágosító témában az olvasók számára, a legjobb szakembereket szerződtette, így Steinberger doktornő is számos cikket írt. ${ }^{75}$

\section{Önvallomás}

Nem tudjuk, hogy a háborút, a vészkorszakot hogyan vészelte át, erre 1962-ben így emlékezett: „A háború alatt leégett a lakásom, és mindenemmel együtt elégtek a korábbi levelek is. A napokban Amerikából kaptam levelet egykori betegemtöl. Megtudta a cimemet és irt. (...) Egyedül vagyok, teljesen egyedül. A háború alatt mindenem és mindenkim elveszett."

Munkájáról és a tudomány fejlődéséről is beszélt a vele készült interjúban: „[N]em is lehet egy napon emliteni a század eleji gyermekhalandóság számát a maival. Persze nemcsak az orvostudomány fejlödése játszott ebben szerepet. Emlékszem rá, a kilencszázas évek elején gyakran elófordult, hogy be sem engedtek a lakásba a szülést levezetni: irtóztak az orvostól. Sok családhoz meg el sem jutott az orvos, különösen vidéken. Kevesen voltunk. (...) Már gyerekkoromban is hittek a kezem gyógyitó erejében." 77

A háború után visszavonult Pesthidegkútra. Később megkapta az arany-, gyémánt- és vasdiplomáját is. Egy vele készült interjúban beszámolt elég szűkös életéről, különösen a nyugdíjas koráról: „A nyugdijamból [élek], szerényen. Ha nem lennék egyedül, persze más lenne a helyzet. De az én koromban már fizetni kell a mosásért, a fózésért, mindenért. De hát összehúzom kissé magam, egész életemben irtóztam a fényüzéstöl. Persze, nehogy azt higgye, hogy az ember, így én is, nem vágyik többre, jobbra..."78 Utolsó pillanatig olvasott, fejlesztette és művelte magát, lépést tartott a szakirodalommal. Végül teljesen magányosan halt meg 1966-ban.

73 A nők világkongresszusa. Háromezer külföldi Budapesten. Magyarország, 1913. június 14. 4.

74 A nők iskolázásának kérdéséről. Az Ujság, 1925. január 10. 9.

75 Mit kap Ön... Ujság, 1928. december 8. 42.

76 Szabó László: A doktor néni. Népszabadság, 1962. október 9. 6-7.

77 Szabó László: A doktor néni. Népszabadság, 1962. október 9. 6-7.

78 Szabó László: A doktor néni. Népszabadság, 1962. október 9. 7. 

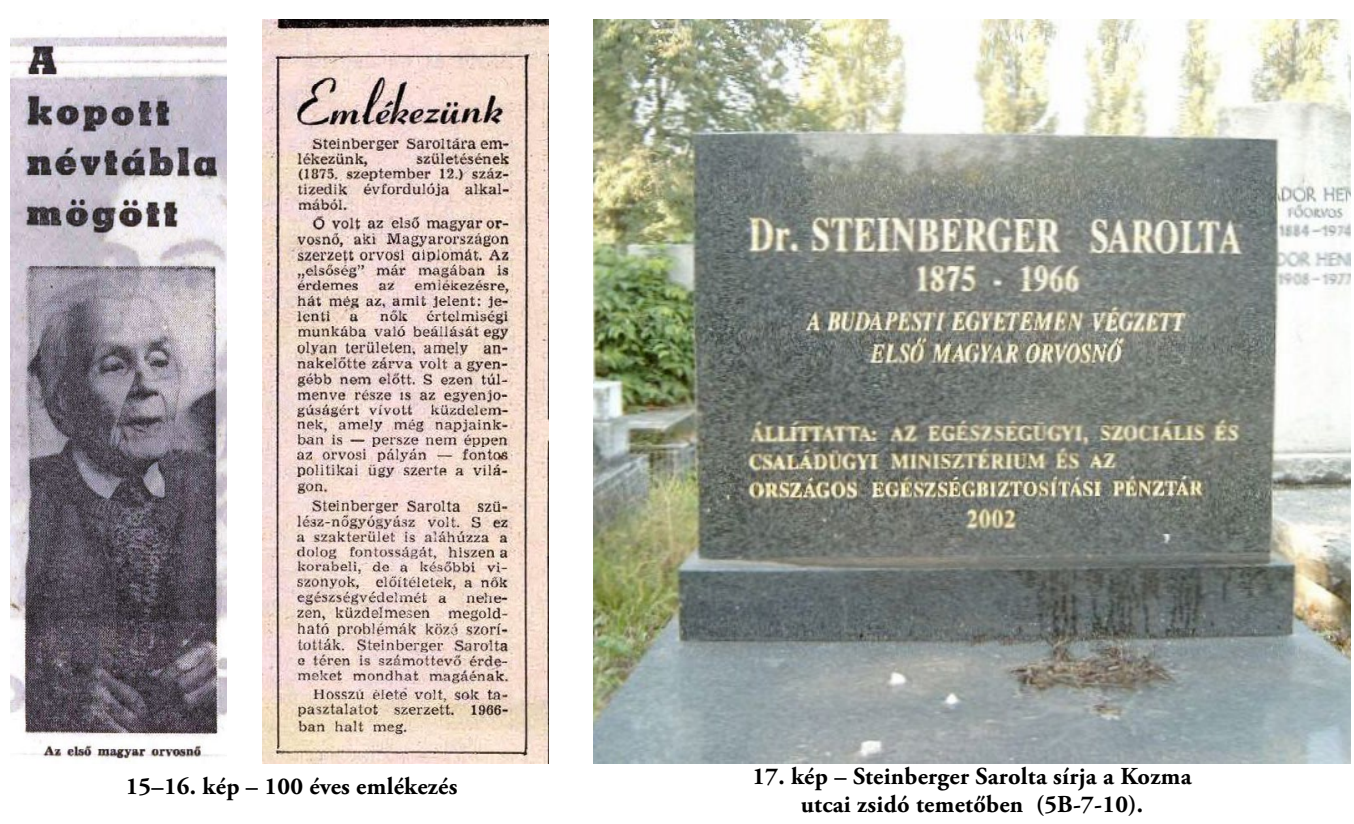

\section{KÉPJEGYZÉK}

1. kép

2. kép

3. kép

4. kép

5. kép

6. kép

7. kép

8. kép
A zsidó honvéd. Népszínmü. Forrás: Szinházi Hét, 1910. február 3. 36 .

Dr. Steinberger Sarolta. Forrás: Radnóti 2012. (http://rabbi. zsinagoga.net/2012/11/26/a-legujabbkori-sara-elete-az-eletetado-eletmesek-xv) [2020.06.25.]

Dr. Steinberger Sarolta. Forrás: RaDnóti 2012. (http://rabbi. zsinagoga.net/2012/11/26/a-legujabbkori-sara-elete-az-eletetado-eletmesek-xv) [2020.06.25.]

Gyakornoki megválasztás. Forrás: Hivatalos Közlöny 1901. 825.

Visk: várhegy gyógyfürdő, gyógyforrás, fürdő épület, igazgatói lak és iroda. Forrás: (https://www.darabanth.com/hu/ gyorsarveres/241/kategoriak - Kepeslapok/Karpatalja 200009/ViskVarhegy-gyogyfurdo-gyogyforras-Furdo-epulet-Igazgatoi-lak-es-irodaspa-direc-II1124943/) [2020.06.25.]

Gynekológus estek. Forrás: Orvosi Hetilap Gynaekologia melléklete (1902):1. 19.

A Budapesti Orvosi Casinoba való belépés elutasítása. Forrás: Független Magyarország, 1904. január 10. 9.

Gondatlan emberöléssel vádolt föorvosnö. Forrás: Új Nemzedék, 1937. október 27. 9. 
9. kép

10. kép

11. kép

12. kép

13. kép

14. kép

15. kép

16. kép

17. kép
Orsós professzor véleménye. Forrás: Magyarország, 1937. október 27. 14.

Dr. Steinberger Sarolta felmentése. Forrás: Friss Újság, 1938. december 24. 5.

Felhívás a víz- és gyógyvízrészvény jegyzésére. Forrás: Budapesti Hirlap, 1938. augusztus 18. 25.

A Magyar Nők Közmivelődési Körének zsúrjáról. Forrás: Fotó: Sorger Sándor, Vasárnapi Ujság, 1906. január 21. 45.

Egészségügyi elöadások nök számára. Forrás: Pesti Napló, 1905. november 24. 15.

Mindent Tudok-előadások. Forrás: Ujság, 1928. december 8. 42.

100 éves emlékezés. Forrás: Magyar Ifjúság, 1965. december 17. 4. 100 éves emlékezés. Forrás: Szabad Föld, 1985. szeptember 14.7. Steinberger Sarolta sírja a Kozma utcai temetőben. Forrás: RadNóTI 2012. (http://rabbi.zsinagoga.net/2012/11/26/a-legujabbkorisara-elete-az-eletet-ado-eletmesek-xv) [2020.06.25.]

\section{SAJTÓFORRÁSOK}

Az Ujság, 1911, 1925

Budapesti Hírlap, 1892, 1896, 1903, 1906, 1911, 1938

Budapesti Napló, 1900

Fővárosi Közlöny, 1902

Független Magyarország, 1903, 1904

Friss Újság, 1938

Gyógyszerészi Hetilap, 1896

Hivatalos Közlöny, 1901

Magyar Ifjúság, 1965

Magyarország, 1901, 1906, 1911, 1913, 1937

Népszabadság, 1962

Népszava, 1907, 1910

Orvosi Hetilap, 1902

Pécsi Napló, 1900

Pesti Hírlap, 1903, 1907, 1911

Pesti Napló, 1903, 1905

Szabad Föld, 1985

Színházi Hét, 1910

Új Nemzedék, 1937 
Ujság, 1928

Vasárnapi Ujság, 1906

Világ, 1911, 1912

\section{ForRÁsOK}

Budapesti Czim- és Budapesti Czim-és lakásjegyzék. 22. (1910) 306. LAKÁSJEGYZÉK 1910

MAGYARORSZÁGI RENDELETEK TÁRA 1895

MiHÓK-FÉLE MAGYAR COMPASS 1896
A vallás- és közoktatásügyi m. kir. ministernek 1895. évi 65.719. szám alatt a budapesti és kolozsvári egyetem tanácsához intézett rendelete, a nőknek a bölcsészeti, orvosi és gyógyszerészi pályára léphetése tárgyában. Magyarországi rendeletek tára 29. (1895.) 1680-1686.

Mihók-féle Magyar Compass. Pénzügyi évkönyv 24. Szerk. Galánthai Nagy Sándor (1896):1.

\section{IRODALOM}

Clement 2018

FORRAI 2019a

FORRAI 2019b

GÝ́NI 1984

HaWKesWorth 2006

JEFFERSON - BLOOR

- MaYNARD 2015

JoвST 2000

KAPRONCZAY 1997
Clement, Grace: Care, Autonomy, and Justice: Feminism and the Ethic of Care. Routledge, 2018.

ForRa Judit: Dr. Kunvári Bella, a modern fogorvosnő, műgyüjtő, kultur-mozgalmár, polihisztor, múzsa. Kaleidoscope (2019):18. 279-290. (http://www.kaleidoscopehistory.hu/index. php?subpage $=c i k k \& c i k k i d=474$ ) [2020.03.29.]

ForRa Judit: Orvosnők társadalmi és szakmai szelekciójának ontológiája. A kezdet. Kaleidoscope (2019):19. 32-58. (http://www. kaleidoscopehistory.hu/index.php?subpage=cikk\&cikkid=498) [2020.03.29.]

GYáni Gábor: A bábától az orvosnőig. História 6. (1984):1.31-34.

Hawkesworth, Mary E.: Globalization and Feminist Activism. Lanham, 2006.

Jefferson, Laura - Bloor, Karen - Maynard, Alan: Women in medicine: Historical perspectives and recent trends. British Medical Bulletin 114. (2015):1. 5-15.

Joвsт Ágnes: Emancipáció és orvoslás. Lege Artis Medicinae 10. (2000):2. 171-174.

Kapronczay Károly: Hugonnai Vilma emlékezete. Orvosi Hetilap 138. (1997):48. 3060-3061. 
KARÁDY 2013

KÉRI 2019

LORBER 1984

MagYar 2018

Orsós 1937

Orsós 1942

Pelle 2018

Péter H. 2018

RADNÓTI 2012

RiSKA 2001

SzÖGI 1986
KaRÁDY Viktor: Kolozsvár, mint iskolaváros a Kárpát-medence elitképzési piacán. In: 140 éves a kolozsvári magyar nyelvü egyetemi oktatás. Szerk. BATız Enikő - NAGy László - Soós Anna. Kolozsvár, 2013. 237-244.

KÉRI Katalin: Viták az orvosnők képzéséről a XIX. század második felében. Orvosi Hetilap 160. (2019):47. 1881-1884.

Lorber, Judith: Women Physicians: Careers, Status, and Power. New York, 1984.

Magyar László András: Egy vitéz doktor. Kaleidoscope (2018):17. 100-104. (http://www.kaleidoscopehistory.hu/index. php?subpage $=$ cikk \& cikkid=418) [2020.03.27.]

Orsós Ferenc: Európa biológiai veszélyeztetettségének leküzdése. MONE 1936. XII. 12. tartott közgyülésén. Budapest, 1937. (Klny. MONE)

Orsós Ferenc felszólalása az országgyűlés felsőházának 49. ülésén, 1941. július 18. In: Az 1939. évi június hó 10-ére hirdetett Országgyülés Felsöházának Naplója. II. kötet. Budapest, 1942. 296.

Pelle János: A magyar orvostársadalom és a „végső megoldás”. Életünk 56. (2018):5-6. 118-144.

PÉTer H. Mária: Nők az egyetemen. Az első okleveles orvosnők és gyógyszerésznők a budapesti felsőoktatásban és a kolozsvári Ferenc József Tudományegyetemen. Erdélyi MúzeumEgyesület 80. (2018):1. 137-151.(https://eda.eme.ro/xmlui/ handle/10598/30921)_[2020.03.27.]

RadNóti Zoltán: Alegújabbkori Sára élete-Azéletet adó-(Életmesék $X V$.) (http://rabbi.zsinagoga.net/2012/11/26/a-legujabbkori-saraelete-az-eletet-ado-eletmesek-xv/) [2020.06.25.]

Riska, Elianne: Medical Careers and Feminist Agendas: American, Scandinavian, and Russian Women Physicians. New York, 2001.

SzöGi László: A nők egyetemi tanulmányainak kérdése a Budapesti Orvostudományi Karon 1896-1926. Orvostörténeti Közlemények 32. (1986):115-116. 139-142. 